〔澱粉科学 (Denpun Kagaku) 第 39 巻 第 4 号 p. 271 276 (1992)〕

\title{
水分吸着・脱離等温線による 澱粉の微細構造の解析
}

\author{
坊木佳人*, 川崎直人*, 南 一生* \\ Structural Analysis of Micropores of Starches by Moisture \\ Adsorption-Desorption Method \\ Keito BOKI,* Naohito KAWASAKI* and Kazuo MINAMI* \\ *Faculty of Pharmaceutical Sciences, Kinki University \\ (3-4-1, Kowakae, Higashi-Osaka 577, Japan)
}

\begin{abstract}
The pore size distribution curves of rice, corn, potato, sweet potato and kuzu starches were investigated to elucidate the relationship between the types of $\mathrm{A}, \mathrm{B}$ and $\mathrm{C}$ forms and their porosity. Pore size distribution curves in the regions of pore radii 4 to $10.5 \AA$ and 10.5 to $300 \AA$ were determined by the micropore (MP) method from the moisture adsorption isotherms and the Barrett Joyner Halenda (BJH) method from the moisture desorption isotherms, respectively. Moisture content at higher water activity than 0.4 , saturated moisture content and hysteresis loop of $B$ form (potato) starch were larger than those of $C$ form (kuzu, sweet potato) and $\mathrm{A}$ form (rice, corn) starches. The maximum peak at the vicinity of pore radius $8 \AA$ was observed not in the $\mathrm{A}$ and $\mathrm{C}$ form starches but in the $\mathrm{B}$ form starch. The plots of pore volume in the region of pore radii 10.5 to $300 \AA$ and $B$ form percentage gave a straight line with correlation coefficient of 0.955 .
\end{abstract}

溊粉は, アミロースとアミロペクチンから構成されて いるが，それらの比は涮粉によって異なる。不破”はア ミロースとアミロペクチンの分子模式図を，檜作ら ${ }^{2)}$ は 結晶領域と非結晶領域からなる澱粉微粒子の結晶構造の 模式㘡を提示している.

澱粉の結晶構造は原植物で異なり, 檜作 ${ }^{33}$ は澱粉の $\mathrm{X}$ 線回折図により A, B , C 図形に分類し，B図形には，20 $=5.5^{\circ}$, 格子間隔 $16 \AA$ にはっきりした回折像があると 報告している．Wu と Sarko4)は，Bーアミロースに护け る分子鎖の配置は， 6 本の 2 本鎖螺旋に取り囲まれ，水 の侵入する大きな空洞があるが，A-アミロースには， 空洞に 7 本目の 2 本鎖螺旋が入っていると報告している. さらに, 今田 ${ }^{5)}$ は, 檜作の X線回折図と Wu と Sarko の 分子模型の結果から, B図形澱粉の中心空洞の内径は $16 \AA$ であると報告している. このように，涮粉の細孔 構造に関する研究は，X線回折図による解析が主であっ

* 近畿大学薬学部 (577 東大阪市小若江 3-4-1)
た。

吸着法によっても微粒子の表面や多孔性物質の細孔構 造に関する情報が得られるが6)，吸着法による涮粉の構 造解析は，これまで皆無に等しい，微粒子の細孔分布を 評価する吸着質として窒素分子と水分子が用いられる7゙. 直野 ${ }^{83}$ は，吸着質として窒素分子を用いた場合， -195.8 'C の極低温で吸着を行うため，測定前に試料が収縮する 場合があると，また，Hellman'は，窒素吸着する場合， $105^{\circ} \mathrm{C}$ で 24 時間 $1.32 \times 10^{-10} \mathrm{~atm}$ で脱気する必要がある と報告している．吸着質として水分子を用いた場合，澱 粉内に水分子が内部吸収される可能性も考えられるが, 加熱による構造変化を受けない状態での澱粉の吸着・脱 離等温線を求めることができる. 水分子(直径約 $2 \AA$ ) は, 窒素分子（直径約 $4.2 \AA$ ）より小さいためより小さ い細孔内に侵入でき，小さい細孔を正確に評価できる8 という報告もある.

コメ澱粉, トウモロコシ澱粉, バレイショ澱粉, 甘藷 澱粉, クズ澱粉の水分吸着・脱離等温線を求め, 水分子 
が澱粉内に吸収されないと仮定して micropore (MP) 法 $^{10)}$ と Barrett Joyner Halenda (BJH) 法11)によって 細孔分布を算出し,これらの使粉の細孔構造について比 較検討した.

\section{実験方法}

\section{1. 試料}

コメ澱粉，トウモロコシ澱粉，バレイショ澱粉，甘藷 澱粉，クズ溊粉の 5 種類を使用した。 クズ澱粉は, 福場 の方法 ${ }^{12}$ とっって調製した，奈良県で採取したクズ根を 細切, 粉砕後, 水晒しを繰り返し, 沈澱物を室温で 5 時 間真空乾燥したものを，コメ澱粉，トウモロコシ澱粉， バレイショ泟粉，甘藷澱粉は，三和澱粉工業製のものを 使用した。 これらの測粉を粒度 470 メッシュ以下に揃兄， 室温で 15 時間 $1.32 \times 10^{-6} \mathrm{~atm}$ で真空脱気したものを使 用した. 真空脱気後の試料は, 熱重量分析の結果, 2.01 $2.30 \%$ の水分を含んでいたが，水分吸着量の算出には無 水澱粉として取り扱った.

\section{2. 水分吸着・脱離等温線}

既報 ${ }^{13)}$ 亿準拠し，柴田水分吸着表面積測定装置 P-850 型 (柴田科学器械製)を使用した。重量法により $20^{\circ} \mathrm{C} に$ 扣ける水分吸着・脱離等温線を水分活性約 $0 \sim 1.00$ の範 囲で求めた，等温線は，3回測定し，その变動係数は $0.394 \sim 1.100 \%$ となり，実験誤差の範囲内で一致した。

\section{3. 細孔分布}

細孔は, その大きさにより，ミクロポアー（細孔半径 $r<20 \AA)$, メソポアー $(20<r<500 \AA)$, マクロポフー $\left(r>500 \AA ̊ 丿\right.$ ）飞分けられる ${ }^{14)}$. 円筒型の細孔と毛管凝縮 は, Kelvin 式(1)で与兄られる。

$$
\log \left(P / P_{0}\right)=-2 \sigma V / 2.303 R T r_{\mathrm{k}}
$$

$P / P_{0}$ は水分活性, $\sigma$ は表面張力, $V$ はモル体積, $R$ は気体定数, $T$ は絶対温度である. 細孔半径 $r_{\mathrm{p}}$ は, $r_{\mathrm{k}}$ (Kelvin 半径) と $t$ (吸着層の厚さ) の和として求まる.

Bhambhani 5 ${ }^{15)}$ は, 微粒子表面の化学組成の違いに より, Hagymassy $ら^{(6)}$ は, BET 式の $C$ 定数の違いによ $\eta, t$ 曲線を分類する必要があると述べている．著者ら は，澱粉粒子表面の極性基の影響を補正するために，

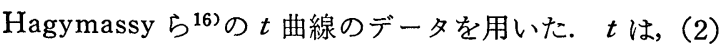
式によって求めることができ，おの拉のの水分活性に対 応する $t$ の值を Table 1 に示した.

$$
t=3.0(\mathrm{~V} / \mathrm{Vm})
$$

$V$ は水分吸着量, $V m$ は単分子吸着量である.

半径 $10.5 \AA$ 以下の細孔分布は, 水分吸着等温線を用 いMP 法 ${ }^{10)}$ で，半径 10.5 300 の細孔分布は，水分脱
Table 1. Statistical thickness versus water

\begin{tabular}{|c|c|c|}
\hline \multirow{2}{*}{$\begin{array}{l}\text { Water } \\
\text { activity }\end{array}$} & \multicolumn{2}{|c|}{ Statistical thickness $(\AA)$} \\
\hline & to $\begin{aligned} C & =10 \\
C & =14.5\end{aligned}$ & $C=23$ \\
\hline 0.010 & 0.90 & 1. 35 \\
\hline 0.025 & 1. 20 & 1.62 \\
\hline 0.050 & 1. 47 & 1. 89 \\
\hline 0.100 & 1. 92 & 2. 37 \\
\hline 0.150 & 2.34 & 2. 82 \\
\hline 0.200 & 2.76 & 3. 24 \\
\hline 0.250 & 3. 12 & 3. 63 \\
\hline 0.300 & 3. 51 & 3. 99 \\
\hline 0.350 & 3. 87 & 4.38 \\
\hline 0.400 & 4. 23 & 4. 68 \\
\hline 0.450 & 4. 71 & 4. 92 \\
\hline 0.500 & 5. 16 & 5. 25 \\
\hline 0.550 & 5.64 & 5. 64 \\
\hline 0.600 & 6. 00 & 6.00 \\
\hline 0.650 & 6. 48 & 6. 48 \\
\hline 0.700 & 6.99 & 6. 99 \\
\hline 0.750 & 7.59 & 7.59 \\
\hline 0.800 & 8.34 & 8. 34 \\
\hline 0.850 & 9.33 & 9. 33 \\
\hline 0.900 & 10.62 & 10.62 \\
\hline 0.925 & 11. 40 & 11.40 \\
\hline 0.950 & 12.45 & 12.45 \\
\hline 0.975 & 14. 04 & 14.04 \\
\hline 0.990 & 17. 16 & 17. 16 \\
\hline 1.000 & 18. 18 & 18. 18 \\
\hline
\end{tabular}
activity.

離等温線を用い $\mathrm{BJH}$ 法 ${ }^{11)} て ゙$ 算出した， MP 法10)による 細孔分布は, $t$ に対して単位重量当りの澱粉に吸着した 水の体積をプロットした $V_{\mathrm{L}}-t$ 曲線を用い，その曲線の 傾きに $t$ を乗じて細孔容積を求め，さらに $t$ に対する細 孔容積を微分することにより算出される． $V_{\mathrm{L}}$ は単位重 量当りに吸着した水分の重量は液体の体積に換算した值 である. $\mathrm{BJH}$ 法 ${ }^{11}$ による細孔分布は， $r_{\mathrm{p}}$ の変化量に対 応した, 単位重量当りの澱粉に吸着した水の体積の変化 量から細孔容積を求め, さらに $r_{\mathrm{p}}$ に対する細孔容積を 微分することにより算出される。

\section{結果と考察}

$20^{\circ} \mathrm{C}$ に扣ける水分吸着・脱離等温線を Fig. 1 5 亿示 した．吸着等温線を比較すると，水分活性 0.4 以上での 水分吸着量は, $\mathrm{B}$ 図形のバレイショ澱粉が最も大きく, 


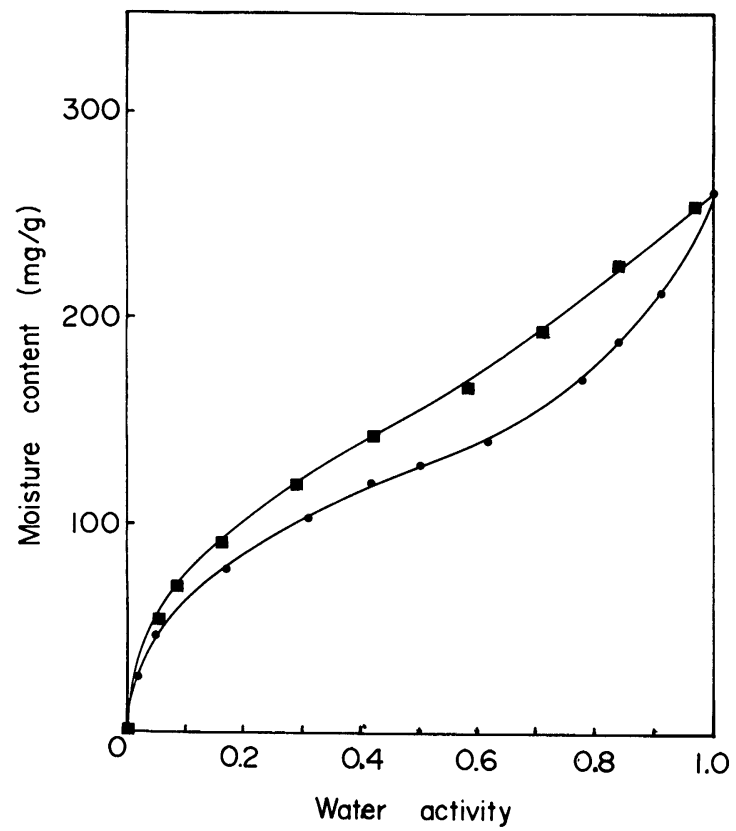

Fig. 1. Moisture adsorption and desorption isotherms at $20^{\circ} \mathrm{C}$ for rice starch.

$\bullet$, adsorption ; $\boldsymbol{\square}$, desorption.

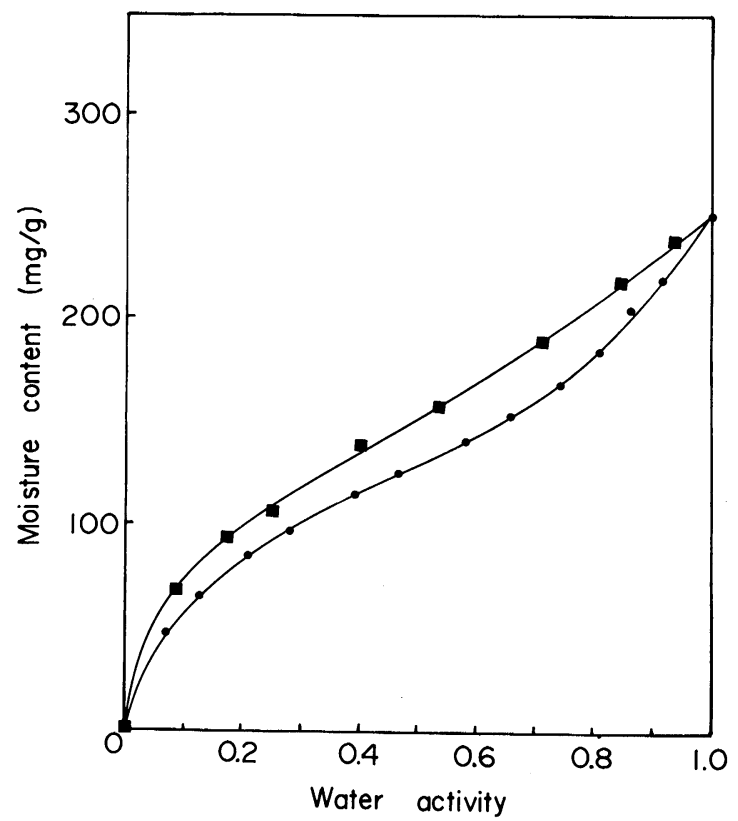

Fig. 2. Moisture adsorption and desorption isotherms at $20^{\circ} \mathrm{C}$ for corn starch.

๑, adsorption; $\boldsymbol{\square}$, desorption.

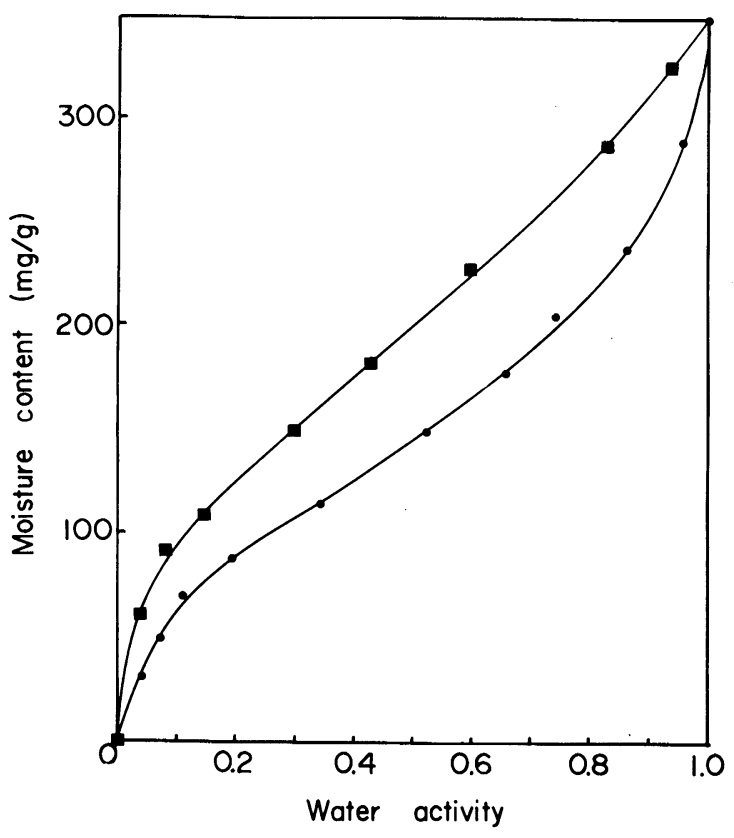

Fig. 3. Moisture adsorption and desorption isotherms at $20^{\circ} \mathrm{C}$ for potato starch.

๑, adsorption ; $\mathbf{\square}$, desorption.

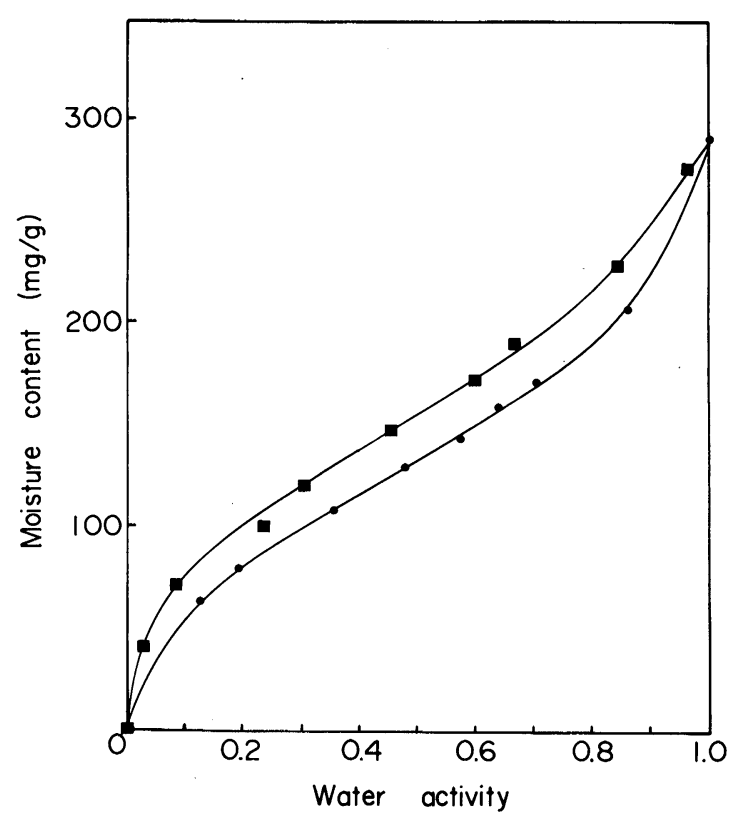

Fig. 4. Moisture adsorption and desorption isotherms at $20^{\circ} \mathrm{C}$ for sweet potato starch.

๑, adsorption; $\mathbf{\square}$, desorption. 


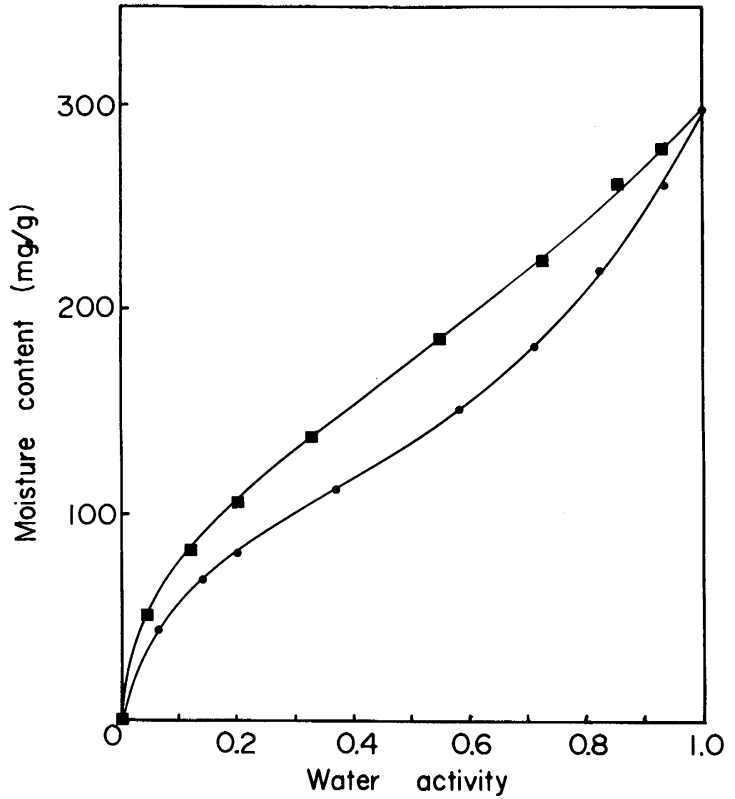

Fig. 5. Moisture adsorption and desorption isotherms at $20^{\circ} \mathrm{C}$ for kuzu starch.

○, adsorption; $\mathbf{a}$, desorption.

$\mathrm{C}$ 図形のクズ洪粉と甘藷測粉, $\mathrm{A}$ 図形のトウモロコシ洪 粉とコメ澱粉の順に小さくなった. 水分活性 1.0 に和け る飽和吸着量を比較すると，バレイショ澱粉は $35 \%$, ク ズ澱粉と甘藷澱粉は $30 \%$, トウモロコシ澱粉とコメ澱 粉は $26 \%$ となった. Van den Berg と Bruin"17)による と, 一般のシグモイド型の等温線は, 三つの部分に大別 され, 水分活性 $0 \sim 0.22$ は範囲 I , $0.22 \sim 0.73$ は範囲 II, $0.73 \sim 1.00$ は範囲 III とされている. さらに, 範囲 II と範 囲 IIIで，水分子は澱粉の膨潤によってできた新しい細孔 中に浸透, 収着すると報告されている. したがって, 高 い水分活性領域での水分吸着能は, 澱粉粒子の微細構造 の安定性によって影響されると考えられる. 檜作 ${ }^{3)}$ は, $\mathrm{B}$ 図形澱粉の微細構造は, $\mathrm{A}$ 図形漸粉よりも不安定であ ると報告している. Fig. 1〜 5 のように，澱粉により水 分吸着量ならびに飽和吸着量が異なる原因は, 澱粉の微 細構造の安定性の差異によるものと考えられる.C図形 澱粉はB図形澱粉之A四形澱粉の混合構造であるため ${ }^{3)}$, $\mathrm{C}$ 図形澱粉の水分吸着量と館和吸着量は, $\mathrm{B}$ 図形澱粉と $\mathrm{A}$ 図形澱粉の拈の拈のの中間值を示したのだと考えられ る.

吸着現象に打けるヒステリシスループは, 脱離等温線 が吸着等温線に重ならず，異なる曲線になる場合に観察 される. Fig. 1〜5 のヒステリシスは，B図形のバレイ
Table 2. Surface area and $C$ constant of starch.

\begin{tabular}{lcccc}
\hline Sample & $\begin{array}{c}\mathrm{BET} \\
\text { constant }\end{array}$ & $\begin{array}{c}S_{\mathrm{BET}} \\
\left(\mathrm{m}^{2} / \mathrm{g}\right)\end{array}$ & $\begin{array}{c}S_{\mathrm{t}} \\
\left(\mathrm{m}^{2} / \mathrm{g}\right)\end{array}$ & $S_{\mathrm{t}} / S_{\mathrm{BET}}$ \\
\hline Rice & 27.0 & 219.6 & 250.0 & 1.138 \\
Corn & 19.2 & 228.4 & 250.0 & 1.095 \\
Sweet potato & 16.7 & 234.4 & 268.0 & 1.143 \\
Kuzu & 18.7 & 231.7 & 274.0 & 1.183 \\
Potato & 16.0 & 249.1 & 288.0 & 1.156 \\
\hline
\end{tabular}

$S_{\mathrm{BET}}$ and $S_{\mathrm{t}}$ were calculated from the BET method and the MP method, respectively.

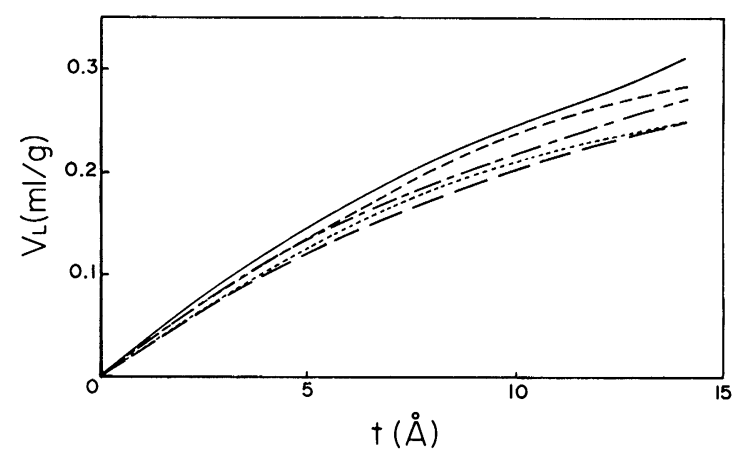

Fig. 6. Volume of adsorbed water versus statistical thickness.

Surface area and pore width were obtained from the slope of $V_{\mathrm{L}}-t$ curve and the abscissa value, respectively.

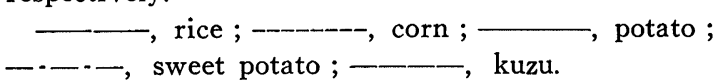

ショ澱粉が最も大きく, C図形のクズ澱粉と甘藷澱粉, $\mathrm{A}$ 図形のトウモロコシ澱粉とコメ澱粉の順に小さくなっ ている. 一般に, ヒステリシスは, 細孔の網目構造とく に細孔の発達の度合に依存するので ${ }^{18)}$ ，これらの結果か ら, 細孔は, $\mathrm{A}$ 図形澱粉, $\mathrm{C}$ 図形港粉, $\mathrm{B}$ 図形搌粉の順 に発達していると考えられる.

水分活性 $0.100 \sim 0.350$ の範囲を BET 式にあてはめ, 定数 $C$ と比表面積 $S_{\mathrm{BET}}$ を算出し Table 2 に示した.

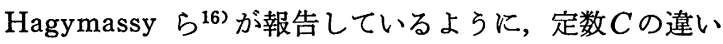
により $t$ 曲線を選択する必要がある. Hagymassy ら ${ }^{16)}$ のデータをるとに算出された Table 1 の, 水分活性と 定数Cの違いによる吸着層の厚さの值を用いた. すなわ ち,コメとトウモロコシ澱粉には $C=23$ のデータを, 甘藷, クズ, バレイショ澱粉には $C=10 \sim 14.5$ のデー タを用いた. $t$ と単位重量当りの澱粉に吸着した水の体 積との関係を $V_{\mathrm{L}}-t$ 曲線 ${ }^{10)}$ として表し, Fig. 6に示した. な拉, Table 2 の比表面積 $S_{\mathrm{t}}$ は, $V_{\mathrm{L}}-t$ 曲線の接線の傾 
きから算出されたものである ${ }^{10)}$. BET 式の定数 $C$ は, 単位表面積当りの吸着剤に対する吸着質の結合力を表す 指標である ${ }^{10)}$. B 図形のバレイショ澱粉の定数 $C$ は Table 2 の中で最も小さく, 次いでC 図形の甘藷激粉之 クズ澱粉，A図形のトウモロコシ澱粉とコメ涮粉の順に 大きくなっている，つまり吸着水と澱粉の結合力は， B

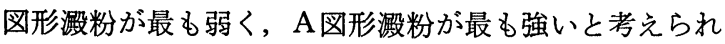
る.

Day とParfitt ${ }^{19}$ は，二酸化チタンの $S_{\mathrm{t}}$ と $S_{\mathrm{BET}}$ を求 め, $S_{\mathrm{t}}$ と $S_{\mathrm{BET}}$ が等しい場合には，吸着前に表面に付着 水が存在していると, 逆に, $S_{\mathrm{t}}$ と $S_{\mathrm{BET}}$ が異なる場合に は，付着水が存在していないと報告している.

Table 2 の $S_{\mathrm{t}}$ は $S_{\mathrm{BET}}$ よりも 9.5〜18.3\%大きいの で，Day と Parfitt の報告によれば，澱粉表面の付着水 は完全に除去されていると考兄られる. したがって, 得 られた水分吸着・脱離等温線のデータは，澱粉表面の真 の状況を正確に反映しているといえる.

水分吸着等温線を MP 法衫にあてはめ, 半径 $10.5 \AA$ 以下の細孔分布を算出し，Fig. 7 に示した。B図形のハ レイショ澱粉には, 細孔半径 $8 \AA$ 付近に大きなピーク が観察されたが，A図形のトウモロコシ澱粉とコメ澱粉 には，そのようなピークが観察されず，檜作 ${ }^{3)}, \mathrm{Wu}$ と Sarko4)，今田5)の結果と一致した。C図形の甘藷涮粉が， $\mathrm{A}$ 図形澱粉と $\mathrm{B}$ 図形澱粉の単なる混合物であるなら，細 孔半径 $8 \AA$ 付近に $\mathrm{A}$ 図形と $\mathrm{B}$ 図形の混合割合に応じた ピークが認められるはずであるが，そのような事実は認

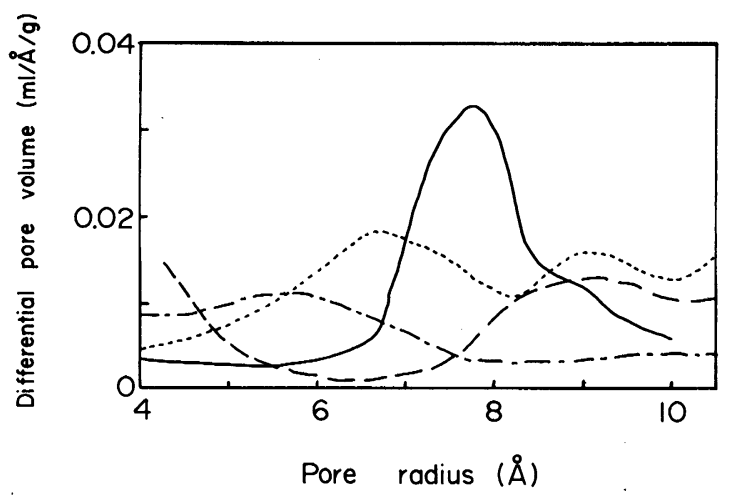

Fig. 7. Micropore size distribution determined by the MP method from moisture adsorption isotherms on starches.

$\longrightarrow$, rice ; ------, corn ; - potato ; ---- , sweet potato. Micropore size distribution of kuzu starch could not be obtained because of negative difference in the slope of $V_{\mathrm{L}}-t$ curve of Fig. 6.

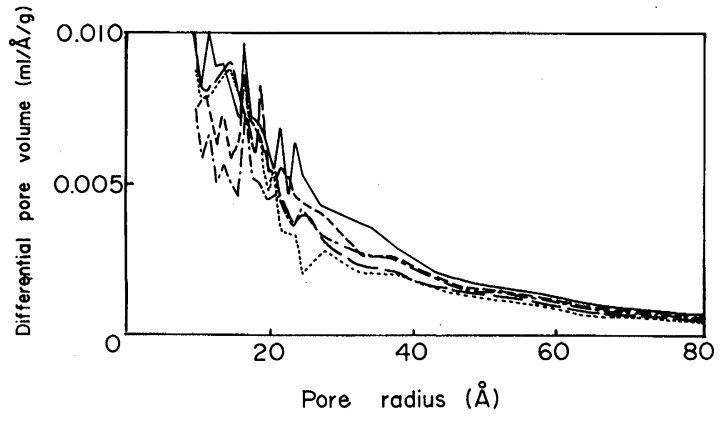

Fig. 8. Pore size distribution determined by the $\mathrm{BJH}$ method from moisture desorption isotherms on starches.
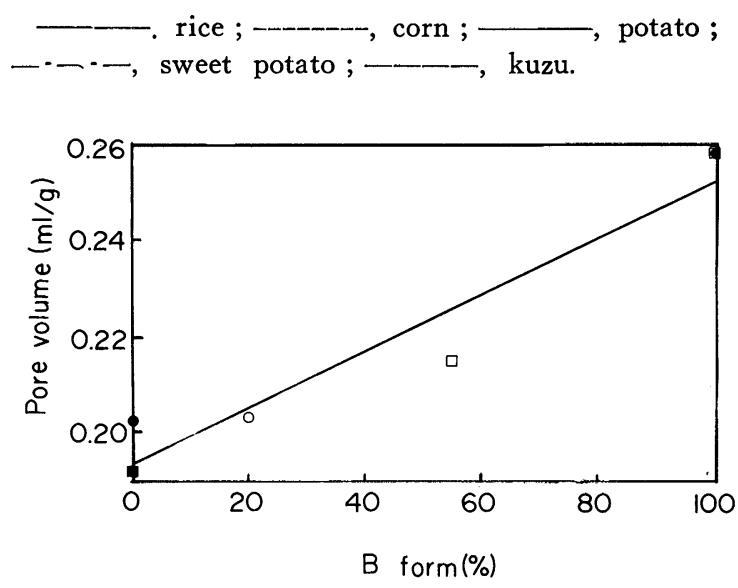

Fig. 9. Relationship between pore volume in the region of pore radii 10.5 to $300 \AA$ and $B$ form percentage of starch.

-, rice ; $\mathbf{\square}$, corn ; $\square$, potato ; $\bigcirc$, sweet potato ; $\square$, kuzu.

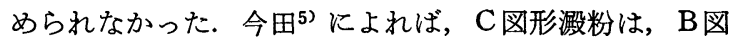
形溊粉の空洞に 2 本鎖螺旋 1 本が，过り込んで部分的に $\mathrm{A}$ 図形澱粉の相が出現していると報告している. C目形 涮粉の空洞が，見掛け上A図形澱粉に類似していると仮 定すれば，C図形甘藷澱粉の細孔半径 $8 \AA$ 付近にピー クが見られない原因は矛盾なく説明される.

水分脱離等温線を $\mathrm{BJH}$ 法 ${ }^{11}$ とあてはめ, 半径 10.5 $300 \AA$ の細孔分布を算出したが, Fig. 8 には半径 10.5 $80 \AA ̊$ の結果のみを示した. Fig. 8 の結果から, 澱粉に

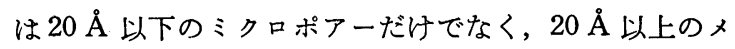
ソポアーも存在していることが観察された. 半径 10.5〜 $300 \AA ̊$ の細孔容積は, B 図形のバレイショ澱粉が最も 大きく， $\mathrm{C}$ 図形のクズ澱粉と甘藷澱粉， $\mathrm{A}$ 図形のトゥモ ロコシ澱粉とコメ澱粉の順に小さくなった. 檜作 ${ }^{3)} の \mathrm{X}$ 
線回折図による結果と著者らの水分吸着法による細孔容 積との相関性を調べるため，B図形澱粉の割合に対して 細孔容積の值をプロットした (Fig. 9). その結果, 両者 の間には直線性が認められ，その直線は，0.955 の相関 係数を示した。 また，MP 法による半径 4〜10.5 ̊ の 細孔容積と $\mathrm{BJH}$ 法による半径 10.5 300 $\AA$ の細孔容積 との和，すなわち，全細孔容積と B 図形溊粉の割合をプ ロットしたところ (図省略)，両者の間には 0.959 の相 関性が認められた．したがって，X線回折図による澱粉 の結晶構造の A, B , C 図形の分類は, 澱粉の細孔容積の 大ささと深い関連性のあることが判明した．さらに，檜 作ら ${ }^{2)}$ が報告している澱粉の微細構造の安定性と $\mathrm{A}$ 図形, $\mathrm{B}$ 図形の関係，ならびに Fig. 8 の結果から，B図形の バレイショ澱粉は $\mathrm{A}$ 図形のコ、澱粉とトウモロコシ澱粉 より空隙が多く存在し，この空腺の大きさが微細構造の 不安定性に関与していると考えられる.

水分吸着・脱離等温線を MP 法と $\mathrm{BJH}$ 法にあてはめ て算出した細孔分布と $\mathrm{X}$ 線回折図から分類された $\mathrm{A}, \mathrm{B}$ ， C 図形との間には，高い相関性のあることが判明した.

\section{要 約}

1） $20^{\circ} \mathrm{C}$ に打ける水分吸着・脱離等温線の結果から, 水分活性 0.4 以上での水分吸着量, 水分活性 1.0 亿打け る飽和吸着量, ヒステリシスの大きさは，B図形のバレ イショ澱粉が最も大きく，C図形のクズ澱粉と甘藷澱粉 $\mathrm{A}$ 図形のトウモロコシ澱粉とコメ涮粉の順に小さくなっ た.

2) 水分吸着等温線を MP 法にあてはめ，半径 10.5 $\AA$ 以下の細孔分布を算出した。 その結果, B図形のバレ イショ激粉には, 細孔半径 $8 \AA$ 付近に大きなピークが 観察されたが，A図形のトゥモロコシ澱粉とコメ澱粉， C 図形の甘藷澱粉には，そのようなピークが観察されな かった.

3）水分脱離等温線を $\mathrm{BJH}$ 法にあてはめ, 半径 10.5〜300 ̊の の細孔分布を算出した，その結果，細孔容 積は，B四形のバレイショ澱粉が最も大きく，C図形の クズ澱粉と甘藷澱粉，A図形のトウモロコシ澱粉とコメ 澱粉の順に小さくなった．X線回折図による B 図形澱粉 の割合と水分吸着法による細孔容積の值をプロットした ところ，直線性（相関係数，0.955）が認められた。ささら
に, 半径 4 10.5 と半径 10.5 300 の の全細孔容積と $\mathrm{B}$ 図形澱粉の割合との間にも 0.959 の相関性が認められ た.

\section{文献}

1) 不破英次：調理科学, 2, 20 (1987).

2）檜作 進, 南戸正夫, 二國二郎：農化，38，520-524 (1964).

3）檜作 進：「測粉科学ハンドブック」, 二國二郎監修, 朝倉書店, 東京, p. 25-34 (1977).

4) H. H. WU and A. SARKO : Carbohydr. Res., 61, 7-25 and 27-40 (1978).

5）今田清久：化学と生物, 20 (2), 106-113（1982）.

6) S. J. GREGG and K. S. W. SING : Adsorption Surface Area and Porosity, 2nd ed., Academic Press, New York, Chap 2-5 (1982).

7) J. D. Carruthers, D. A. Payne, K. S. W. Sing and L. J. STRYKer : J. Colloid Interface Sci., 36, 205-216 (1971).

8）直野博光，白曼雅子：表面, 29 (5), 362-373 (1991).

9) N. N. Hellman and E. H. Melvin : J. Am. Chem. Soc., 72, 5186-5188 (1950).

10) R. S. Mikhail, S. BRUNAUER and E. E. Bodor: J. Colloid Interface Sci., 26, 45-53 (1968).

11) E. P. BARRETT, L. G. JOYNER and P. P. HALENDA : J. Am. Chem. Sci., 73, 373-380 (1951).

12）福場博保:「泚粉科学ハンドブック」, 二國二郎監修, 朝倉書店, 東京, p. 166（1977）。

13) K. BoKI, S. OHNo and S. SHINOdA : J. Food Sci., 54(2), 487-488 (1989).

14) S. J. GREGG and K. S. W. SiNG : Adsorption Surface Area and Porosity, 2nd ed., Academic press, New York, p. 25 (1982).

15) M. R. Bhambhani, P. A. Cutting, K. S. W. SING and D. H. TURK : J. Colloid Interface Sci., 38, 109-117 (1972).

16) J. HAGYMASSY, Jr., S. BRUNAUER and R. S. MikhaIL: J. Colloid Interface Sci., 29, 485491 (1969).

17) C. VAN DEN BERG and S. BRUIN : Water Activity: Influences on Food Quality, L. B. RockLAND and G. F. STEWART, eds., Academic Press, New York, p. 1 (1981).

18）盛岡良雄: Adsorption News, 6, 8-11 (1992).

19) R. E. DAY and G. D. PARFITT : Trans. Faraday Soc., 63, 708-716 (1967).

（平成 4 年 6 月 1 日受付，平成 4 年 6 月 29 日受理） 